\title{
Influence of hydrophile-lipophile balance and sodium tripolyphosphate on the properties of biological deinked pulps
}

\author{
N. Mayeli ${ }^{1} \cdot$ M. Talaeipour ${ }^{1}$
}

Received: 20 October 2013/Revised: 10 November 2014/ Accepted: 14 March 2015/Published online: 9 April 2015

(C) Islamic Azad University (IAU) 2015

\begin{abstract}
The benefits of bio-deinking of waste paper are investigated in this study. Enzymatic modification of mixed office waste paper and old magazine pulps was performed at two temperatures, 20 and $50{ }^{\circ} \mathrm{C}$. Nonionic surfactant with different hydrophile-lipophile balance values and sodium tripolyphosphate was used as the deinking agent. The deinking process was conducted for pulps with and without enzymatic treatment. The results show that, for mixed office waste paper and old magazine pulps, the highest strength properties are achieved using lower hydrophile-lipophile balance at 20 and $50{ }^{\circ} \mathrm{C}$, respectively, while using higher hydrophile-lipophile balance has a significant influence on the optical properties at $50{ }^{\circ} \mathrm{C}$. Further, the results show in the presence of sodium tripolyphosphate, the optical properties of treated pulps, especially old magazine pulp significantly improved at $20^{\circ} \mathrm{C}$ (ESST system). For mixed office waste paper, the optimum values of burst, tear and tensile indices, folding endurance, E-MOD, tensile energy absorption and elongation are $2.97\left(\mathrm{kPa} \mathrm{m}^{2} / \mathrm{g}\right), \quad 7.68$ $\left(\mathrm{mN} \mathrm{m}^{2} / \mathrm{g}\right), 93.47(\mathrm{~N} \mathrm{~m} / \mathrm{g}), 13,8024(\mathrm{GPa}), 100.16\left(\mathrm{~J} / \mathrm{m}^{2}\right)$ and $2.53(\%)$, respectively. Moreover, the results from measuring optical properties of handsheets show that the optimum values of brightness, dirt count, dirt area and deinking efficiency are $44.72(\%), 11,0.221\left(\mathrm{~mm}^{2}\right)$ and 78.07 (\%) correspondingly, while for old magazine, the formers are $2.35\left(\mathrm{kPa} \mathrm{m}^{2} / \mathrm{g}\right), 6.77\left(\mathrm{mN} \mathrm{m}^{2} / \mathrm{g}\right), \quad 77.77$ $(\mathrm{N} \mathrm{m} / \mathrm{g}), 9,6199(\mathrm{GPa}), 72.61\left(\mathrm{~J} / \mathrm{m}^{2}\right)$ and $2.37(\%)$ and
\end{abstract}

N. Mayeli

nader.mayeli@manchester.ac.uk

1 Department of Wood and Paper, Science and Research Branch, Islamic Azad University, Tehran, Iran the latters are $60.93(\%), 1,0.005\left(\mathrm{~mm}^{2}\right)$ and $99.52(\%)$, respectively.

Keywords Enzymatic modification - Mixed office waste paper $\cdot$ Old magazine $\cdot$ Temperature $\cdot$ Surfactant $\cdot$ Deinking efficiency

\section{Introduction}

An increasing interest in bio-deinking suggests that it is vital to gain a better insight into fundamental of biological deinking and its effect on the pulp and paper properties. Deinking is the key process in waste paper recycling (Fricker et al. 2007). The drawback of the current deinking process is laid on the use of large amount of environmentally damaging chemicals which is also expensive (Bobu et al. 2008; Hannuksela and Rosencrance 2008; Jeffries et al. 1994, 1995; Morrow et al. 2005; Sykes and Tan 1997; Xu et al. 2011). The new biotechnical methods use enzymes instead of chemicals in deinking, which causes significant improvements in the pulp and paper manufacturing processes (Ibara et al. 2012; Jeffries et al. 1995; Senior and Hamilton 1992; Vyas and Lachke 2003; Zhang et al. 2008). Unlike the chemicals, enzymes are environmentally friendly (Gübitz et al. 1998; Heise et al. 1997; Knudsen et al. 1998; Marques et al. 2003; Mayeli and Talaeipour 2010; Oh et al. 1997; Patrick 2004; Pèlach et al. 2003; Rutledge-Cropsey et al. 1998; Sykes et al. 1998; Xu et al. 2009; Zeyer et al. 1994) and are of key importance both in the design of new applications and in optimization, and improvement of existing ones. When enzymes are used, the release of ink particles into suspension is attributed to the cellulose hydrolysis on the fiber/ink inter-bonding regions, which facilitates ink detachment. It is reported that 
enzymes can remove small fibrils from the surface of the ink particles (Heise et al. 1997; Sykes et al. 1998). As a consequence of it, the relative hydrophobicity of the particles is altered, which facilitates their separation in the flotation or washing step. To improve their action, nonionic surfactants interact with cellulases. This often enhances enzymatic deinking (Jeffries et al. 1995). According to Jeffries et al. (1994 and 1995), surfactant has a strong effect on the enzymatic deinking efficiency.

Jeffries et al. (1994) reported that pulps treated with enzyme and surfactant showed the lowest number of residual toner particles. As it is known, hydrophile-lipophile balance (HLB) value and cloud point, the balanced characteristics between lipophilic and hydrophilic properties of the surfactants are the most important physical parameters of nonionic surfactants. HLB is an empirical expression for relationship between the hydrophilic (water-loving) and hydrophobic (water-hating) groups of surfactants. With the higher HLB value, the more water-soluble surfactant can be traced. Cloud point is temperature above which an aqueous solution of a water-soluble surfactant becomes turbid. Generally, nonionic surfactants show optimal effectiveness when used near or below their cloud point. The influence of different HLB values of surfactant on enzymatic deinking is discussed by Oh et al. (1997) and Mayeli and Talaeipour (2010). Oh et al. (1997) discussed that surfactant of high HLB value was favorable for stability of cellulose and low HLB value surfactant was favorable to ink removal in flotation process. In agreement with $\mathrm{Oh}$ et al., Mayeli and Talaeipour (2010) reported that the treated old newspaper (ONP) pulps with commercial cellulase and floated with low HLB value had the lowest ink area and dirt count. They also reported that mechanical and optical properties of enzymatic ONP deinked pulps with surfactant of low HLB value were higher than surfactant of high HLB value.

Despite the considerable advancement during last 30 years in the field of enzymatic deinking, there has still been relatively little work reported on the influence of HLB value of surfactant on the enzymatic deinking process and its effect on the pulp and paper properties. In this paper, mixed office waste paper (MOW) and old magazine (OMG) pulps treated with two different enzymatic treatments at two different temperatures and deinked with a nonionic surfactant with two different HLB values and sodium tripolyphosphate (STTP). The essay argues firstly, the effect of various HLB values of a nonionic surfactant on enzymatic deinking of MOW and OMG, secondly, the influence of STTP on the improving of optical properties of handsheets made from MOW and OMG deinked pulps. Sodium tripolyphosphate with formula $\mathrm{Na}_{5} \mathrm{P}_{3} \mathrm{O}_{10}$ is considered an additive in enzymatic deinking of waste papers for the first time in this essay. Note: for having a better comparison, the results from our previous study in ONP enzymatic deinking are added (Mayeli and Talaeipour 2010).

Date and location of the research: May 2012, Science and Research Branch, Islamic Azad University, Tehran, Iran.

\section{Materials and methods}

A mixture of office wastepaper (MOW) collected which includes $40 \%$ copy paper, $40 \%$ laser-printed paper, $10 \%$ notebook paper and $10 \%$ book paper, and also, various mixed old magazines (OMG) are used as the raw material for the production of pulp in this research. Once selected, the MOW and OMG are shredded into approximate $2 \times 2 \mathrm{~cm}$ pieces. After that, the solid form of the Commercial celluzyme ${ }^{\circledR}$, produced from Humicola insolens, and Lipolase ${ }^{\mathrm{TM}}$, produced from Aspergilllus oryzae, Novo Nordisk, Bagvard A/S, Denmark, all supplied from Mahde-Tage Co., Tehran, Iran (based on oven-dried weight of pulp), are added into the pulper at $0.1 \%$. Pulping is done at $4 \%$ consistency, using softened tap water at two temperature 20 and $50{ }^{\circ} \mathrm{C}$ with a laboratorial mixer at the low agitation setting. Pulping at this stage lasts for up to $2.5 \mathrm{~min}$. After that, the enzymatic treatment is being applied for $30 \mathrm{~min}$ in Ben Mari water bath. The original PH of the pulp for MOW and OMG, after enzymatic treatment, is approximately 7.8 and 8 , respectively.

On the next step, for both the MOW and the OMG four liters (containing $40 \mathrm{~g}$ oven-dried fiber) of the pulped slurry are transferred separately to a 5-L capacity standard laboratory flotation cell and float for $10 \mathrm{~min}$. at $1 \%$ consistency, with $0.5 \%$ nonionic surfactant and $1 \%$ STTP, based on oven-dried weight of pulp. The applied surfactant and STTP provided from Kimyagaran Emrooz Co., Tehran, Iran. On the last step, froth is scraped off manually and drains over a 120-Mesh laboratory screen. The outcomes of these processes are five kinds of pulp. These pulps are the control pulp without any treatment, enzyme treated pulps $(E)$, treated pulps with surfactant only $(S)$, treated pulps with enzyme and surfactant $(E S)$, and enzyme treated pulps with surfactant and STTP (ESST). The characteristics of the used surfactant are listed in Table 1. For the analysis facility and statistical calculations, 12.4 and 14.6 HLB were referred to 12 and 15 , respectively.

Note: To improve the detergency power of a surfactant, the deinking process should be done near the cloud point of it by adding a hydrotrope to the detergent formulation to reduce the cloud point. STTP is mainly used to reduce the cloud point of ethoxylated fatty alcohol which is the effective detergent of the formulation. It is worth noting that increasing the temperature is not economical. 
Table 1 Specifications/ Properties of surfactants

\begin{tabular}{llclll}
\hline Name & Composition & $\mathrm{EO}^{\mathrm{a}}(\mathrm{mol})$ & $\mathrm{HLB}^{\mathrm{b}}$ & Cloud point $\left({ }^{\circ} \mathrm{C}\right)$ & $\mathrm{pH}(5 \%$ in water $)$ \\
\hline KELA-7 & Ethoxylated Fatty Alcohol & 7 & 12.4 & $56-64$ & $5-7$ \\
KELA-12 & Ethoxylated Fatty Alcohol & 12 & 14.6 & 74 & $6-7$ \\
\hline
\end{tabular}

${ }^{a}$ Ethylene oxide

b Hydrophile-lypophile balance

The handsheets for strength, optical and image analysis measurement are made by LabTech Semi Automatic Sheet Machine. They are according to the TAPPI test method 205 om-88 procedure. The residual dirt counts and ink areas before and after flotation on a commercially available image analyzer are counted. The image analysis (IA) of the handsheets made from MOW and OMG pulps is done by the use of a PC, Konica Minolta ScanJet 3c Scanner Model C450 and LECIA QWEEN COLOUR program. Scanning resolution is $600 \mathrm{dpi}$, threshold is 140 and the analyzed area of handsheets is $1 \mathrm{~cm}^{2}$ for each repeat. All handsheets are analyzed from the same side (opposite to the mesh side). The brightness of the handsheets is measured according to the TAPPI test method T 452-om 98 .

\section{Results and discussion}

\section{Mechanical properties}

\section{Treated pulps with enzyme only (E)}

As shown in Tables 2 and 3, the enzymatic treatment increases all mechanical properties compared to control pulp for both MOW and OMG pulps. For MOW treated pulps, the improvement in paper strength appears to be more effective after treating the pulps with celluzyme at $20 \mathrm{c}$. The burst index, E-MOD, elongation, breaking length and folding endurance for control pulp are $2.33 \mathrm{kPa} \mathrm{m}^{2} / \mathrm{g}, 6252$ $\mathrm{GPa}, 1.88 \%, 6.47 \mathrm{~km}$ and 6 , respectively, whereas the values for treated pulps are 2.76, 6894, 2.52, 8.7 and 13, respectively. For OMG pulps, there is a reduction in pulp freeness. It can be attributed to the fine particles. Generally, the amount of fines content of a recycled pulp is usually higher than a virgin pulp and so some reduction in drainage rate can be expected.

The OMG treated pulps show a better strength properties using celluzyme/lipolase at $50{ }^{\circ} \mathrm{C}$. For OMG treated pulps, the formers are $1.64,4463,2.09,5.02$ and 5, respectively, and the latters are 1.79, 5010, 2.01, 5.762 and 4, respectively. In agreement with literature, enzymatic treatment through developing internal fibrillation in fiber walls can enhance fiber-bonding ability (Jeffries et al. 1995; Sykes et al. 1998; Mayeli and Talaeipour 2010). In addition to the effect of celluzyme in fiber fibrillation, the lipolase also has a significant influence in improving the strength properties, i.e., lipolase is able to operate as an agent in eliminating the hydrophobic agents (oil-based inks) in pulp slurry (Nakano 1993; Mayeli and Talaeipour 2010).

\section{Treated pulps with surfactant only $(S)$}

Treating the MOW and OMG pulps with surfactant only also influences deinking (Tables 2, 3). In agreement with Mayeli and Talaeipour (2010), all of strength properties increased meaningfully compared with control pulp. For both MOW and OMG pulps, a better improvement is seen for treated pulps using HLB 12 at 20 and $50{ }^{\circ} \mathrm{C}$, respectively. The burst index, E-MOD, elongation, breaking length and folding endurance for MOW treated pulp are $2.67 \mathrm{kPa} \mathrm{m}^{2} / \mathrm{g}, 6922 \mathrm{GPa}, 2.46 \%, 8.9 \mathrm{~km}$ and 9, respectively, whereas the values for OMG treated pulps are 1.87 , $5556,2.03,7.48$ and 6 , respectively. The flotation process results in eliminating of non-fibrous (inorganic or ash) particles in pulp, and possibly, this would lead to an increase in the potential of fiber-to-fiber contact and bonding ability.

\section{Treated pulps with enzyme and surfactant (ES)}

Our enzyme/surfactant system shows that the pulp treatment based on the combination of enzyme and surfactant is the most effective treatment toward other pulp's treatment (Tables 2, 3). As can be seen, for both MOW and OMG treated pulps, the highest strength properties are achieved with combination of celluzyme/lipolase using HLB 12 at $20{ }^{\circ} \mathrm{C}$ for MOW, and at $50{ }^{\circ} \mathrm{C}$ for OMG pulps. In simultaneous enzymatic treatment and flotation process, enzymatic treatment results in improving fiber fibrillation (Mayeli and Talaeipour 2010; Xu et al. 2009; Heise et al. 1997), and the non-fibrous particles removed by the flotation process. So, it seems that combining these two processes can improve potential of inter-fiber bonds between the fibers. The burst index, E-MOD, elongation, breaking length and folding endurance for MOW treated pulp are $2.97 \mathrm{kPa} . \mathrm{m}^{2} / \mathrm{g}, 8024 \mathrm{GPa}, 2.46 \%$, $9.53 \mathrm{~km}$ and 12 , respectively, whereas the values for OMG treated pulps are 2.11, 6199, 2.37, 7.93 and 7, respectively. 
Table 2 Effect of enzyme, HLB and STTP on the pulp and properties of MOW

\begin{tabular}{|c|c|c|c|c|c|c|}
\hline Assay $^{\mathrm{A}}$ & $\mathrm{CSF}(\mathrm{mL})$ & Burst index $(\mathrm{kPa} \mathrm{m} / \mathrm{g})$ & E-MOD (GPa) & Elongation (\%) & Breaking length $(\mathrm{km})$ & Folding endurance \\
\hline Control & 482 & 2.333 & 6252 & 1.88 & 6.466 & 6 \\
\hline \multicolumn{7}{|l|}{$E$} \\
\hline $\mathrm{C}^{\mathrm{a}}$ & 455 & 2.756 & 6894 & 2.52 & 8.7 & 13 \\
\hline $\mathrm{C}^{\mathrm{b}}$ & 521 & 2.561 & 6626 & 2.26 & 8.033 & 7 \\
\hline$(\mathrm{C}+\mathrm{L})^{\mathrm{a}}$ & 491 & 2.685 & 6914 & 2.33 & 8.376 & 6 \\
\hline$(\mathrm{C}+\mathrm{L})^{\mathrm{b}}$ & 485 & 2.365 & 6538 & 2.31 & 7.655 & 6 \\
\hline \multicolumn{7}{|l|}{$S$} \\
\hline $\mathrm{H} 12^{\mathrm{a}}$ & 526 & 2.675 & 6922 & 2.465 & 8.905 & 9 \\
\hline $\mathrm{H} 12^{\mathrm{b}}$ & 481 & 2.505 & 6617 & 2.226 & 8.144 & 8 \\
\hline $\mathrm{H} 15^{\mathrm{a}}$ & 516 & 2.374 & 6749 & 2.458 & 8.404 & 7 \\
\hline $\mathrm{H} 15^{\mathrm{b}}$ & 531 & 2.548 & 6393 & 2.333 & 7.852 & 9 \\
\hline \multicolumn{7}{|l|}{$E+S$} \\
\hline$(\mathrm{C}+\mathrm{H} 12)^{\mathrm{a}}$ & 477 & 2.831 & 7836 & 2.49 & 9.156 & 9 \\
\hline$(\mathrm{C}+\mathrm{H} 12)^{\mathrm{b}}$ & 494 & 2.604 & 7287 & 2.14 & 8.708 & 9 \\
\hline$(\mathrm{C}+\mathrm{H} 15)^{\mathrm{a}}$ & 519 & 2.682 & 7469 & 2.2 & 8.923 & 8 \\
\hline$(\mathrm{C}+\mathrm{H} 15)^{\mathrm{b}}$ & 523 & 2.95 & 7387 & 2.45 & 8.61 & 11 \\
\hline$(\mathrm{C}+\mathrm{L}+\mathrm{H} 12)^{\mathrm{a}}$ & 487 & 2.968 & 8024 & 2.46 & 9.528 & 12 \\
\hline$(\mathrm{C}+\mathrm{L}+\mathrm{H} 12)^{\mathrm{b}}$ & 522 & 2.942 & 7673 & 2.48 & 9.303 & 10 \\
\hline$(\mathrm{C}+\mathrm{L}+\mathrm{H} 15)^{\mathrm{a}}$ & 538 & 2.72 & 7220 & 2.5 & 8.687 & 8 \\
\hline$(\mathrm{C}+\mathrm{L}+\mathrm{H} 15)^{\mathrm{b}}$ & 540 & 2.581 & 6920 & 2.33 & 8.684 & 6 \\
\hline \multicolumn{7}{|l|}{$E+S+S T$} \\
\hline$(\mathrm{C}+\mathrm{H} 12+\mathrm{ST})^{\mathrm{a}}$ & 564 & 2.561 & 7096 & 2.53 & 8.588 & 7 \\
\hline$(\mathrm{C}+\mathrm{H} 15+\mathrm{ST})^{\mathrm{a}}$ & 520 & 2.56 & 7260 & 2.22 & 8.4 & 8 \\
\hline$(\mathrm{C}+\mathrm{L}+\mathrm{H} 12+\mathrm{ST})^{\mathrm{a}}$ & 589 & 2.428 & 6999 & 2.43 & 8.357 & 7 \\
\hline$(\mathrm{C}+\mathrm{L}+\mathrm{H} 15+\mathrm{ST})^{\mathrm{a}}$ & 543 & 2.361 & 7160 & 2.16 & 8.248 & 6 \\
\hline
\end{tabular}

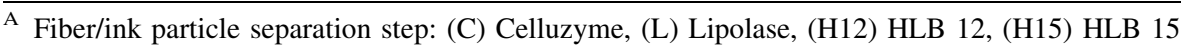

a $20{ }^{\circ} \mathrm{C},{ }^{\text {b }} 50{ }^{\circ} \mathrm{C}$

$E$ Treated pulps with enzyme only

$S$ Treated pulps with surfactant only

ST STTP

Treated pulps with enzyme, surfactant and STTP (ESST)

As shown in Tables 2 and 3, the ESST treatment increases all of the strength properties for MOW pulps. The improvement in paper strength appears to be more effective after treating the pulps with celluzyme using HLB 12. The burst index, E-MOD, elongation, breaking length and folding endurance for MOW treated pulp are $2.56 \mathrm{kPa} \mathrm{m}^{2}$ / g, $7096 \mathrm{GPa}, 2.53 \%, 8.59 \mathrm{~km}$ and 7, respectively. However, for OMG pulps, there is no noticeable improvement in strength properties when STTP is added to the pulps.

The tensile index and TEA of the sheets formed from the MOW and OMG pulps are plotted against the control pulp and the different fiber/ink particle separation steps in Fig. 1a, b.

For both MOW and OMG pulps, the highest tensile index is seen in pulp treated with combination of celluzyme/lipolase and with the HLB 12 at $50{ }^{\circ} \mathrm{C}$ which is 93.47 N m/g and 77.77, respectively.

Regarding the strength properties that are dependent to inter-fibrous bonds, enzymatic treatment through developing internal fibrillation in fiber walls can enhance inter-fiber bonds. Also, the highest TEA is seen in MOW pulp treated with celluzyme using HLB 12 and STTP at $20{ }^{\circ} \mathrm{C}$ which is $100.16 \mathrm{~J} / \mathrm{m}^{2}$. For OMG pulps, the highest TEA is seen in treated pulp with combination of celluzyme/lipolase using HLB 15 at $50{ }^{\circ} \mathrm{C}$ which is 72.62 .

The effect of different fiber/ink particles separation steps on tear index of the sheets formed from MOW and OMG pulps is shown in Fig. 1c. As can be seen, for MOW pulps, the treated pulp with HLB 12 at $20^{\circ} \mathrm{C}$ $(S)$ shows the highest tear index of $7.68 \mathrm{mNm}^{2} / \mathrm{g}$, while for OMG pulps, the highest tear index is seen in treated 
Table 3 Effect of enzyme, HLB and STTP on the pulp and properties of OMG

\begin{tabular}{|c|c|c|c|c|c|c|}
\hline Assay $^{\mathrm{A}}$ & $\mathrm{CSF}(\mathrm{mL})$ & Burst index $\left(\mathrm{kPa} \mathrm{m}^{2} / \mathrm{g}\right)$ & E-MOD (GPa) & Elongation (\%) & Breaking length $(\mathrm{km})$ & Folding endurance \\
\hline Control & 213 & 1.64 & 4463 & 5.017 & & 5 \\
\hline \multicolumn{7}{|l|}{$E$} \\
\hline $\mathrm{C}^{\mathrm{a}}$ & 200 & 1.646 & 4765 & 1.86 & & 3 \\
\hline$C^{b}$ & 194 & 1.712 & 5069 & 5.326 & & 5 \\
\hline$(\mathrm{C}+\mathrm{L})^{\mathrm{a}}$ & 149 & 1.77 & 4862 & 5.211 & & 4 \\
\hline$(\mathrm{C}+\mathrm{L})^{\mathrm{b}}$ & 153 & 1.787 & 5010 & 5.762 & & 4 \\
\hline \multicolumn{7}{|l|}{$S$} \\
\hline $\mathrm{H} 12^{\mathrm{a}}$ & 220 & 1.82 & 5108 & 1.81 & & 5 \\
\hline $\mathrm{H} 12^{\mathrm{b}}$ & 139 & 1.87 & 5556 & 7.48 & & 6 \\
\hline $\mathrm{H} 15^{\mathrm{a}}$ & 185 & 1.80 & 4488 & 5.663 & & 7 \\
\hline $\mathrm{H} 15^{\mathrm{b}}$ & 153 & 1.89 & 5261 & 6.786 & & 6 \\
\hline \multicolumn{7}{|l|}{$E+S$} \\
\hline$(\mathrm{C}+\mathrm{H} 12)^{\mathrm{a}}$ & 220 & 1.879 & 5249 & 5.978 & & 4 \\
\hline$(\mathrm{C}+\mathrm{H} 12)^{\mathrm{b}}$ & 195 & 2.245 & 5575 & 6.801 & & 9 \\
\hline$(\mathrm{C}+\mathrm{H} 15)^{\mathrm{a}}$ & 189 & 2.037 & 4862 & 6.406 & & 4 \\
\hline$(\mathrm{C}+\mathrm{H} 15)^{\mathrm{b}}$ & 191 & 2.116 & 5462 & 7.089 & & 7 \\
\hline$(\mathrm{C}+\mathrm{L}+\mathrm{H} 12)^{\mathrm{a}}$ & 229 & 1.948 & 4912 & 6.135 & & 5 \\
\hline$(\mathrm{C}+\mathrm{L}+\mathrm{H} 12)^{\mathrm{b}}$ & 200 & 2.111 & 6199 & 7.927 & & 7 \\
\hline$(\mathrm{C}+\mathrm{L}+\mathrm{H} 15)^{\mathrm{a}}$ & 218 & 2.129 & 5481 & 7.099 & & 4 \\
\hline$(\mathrm{C}+\mathrm{L}+\mathrm{H} 15)^{\mathrm{b}}$ & 203 & 2.352 & 5097 & 7.225 & & 6 \\
\hline$E+S+S T$ & & & & & & \\
\hline$(\mathrm{C}+\mathrm{H} 12+\mathrm{ST})^{\mathrm{a}}$ & 137 & 1.716 & 4428 & 5.798 & & 4 \\
\hline$(\mathrm{C}+\mathrm{H} 15+\mathrm{ST})^{\mathrm{a}}$ & 136 & 1.763 & 4665 & 6.05 & & 6 \\
\hline$(\mathrm{C}+\mathrm{L}+\mathrm{H} 12+\mathrm{ST})^{\mathrm{a}}$ & 123 & 1.73 & 4505 & 5.645 & & 4 \\
\hline$(\mathrm{C}+\mathrm{L}+\mathrm{H} 15+\mathrm{ST})^{\mathrm{a}}$ & 131 & 1.539 & 4319 & 4.951 & & 3 \\
\hline
\end{tabular}

${ }^{\mathrm{A}}$ Fiber/ink particle separation step: (C) Celluzyme, (L) Lipolase, (H12) HLB 12, (H15) HLB 15

a $20{ }^{\circ} \mathrm{C},{ }^{\mathrm{b}} 50{ }^{\circ} \mathrm{C}$

$E$ Treated pulps with enzyme only

$S$ Treated pulps with surfactant only

ST STTP 

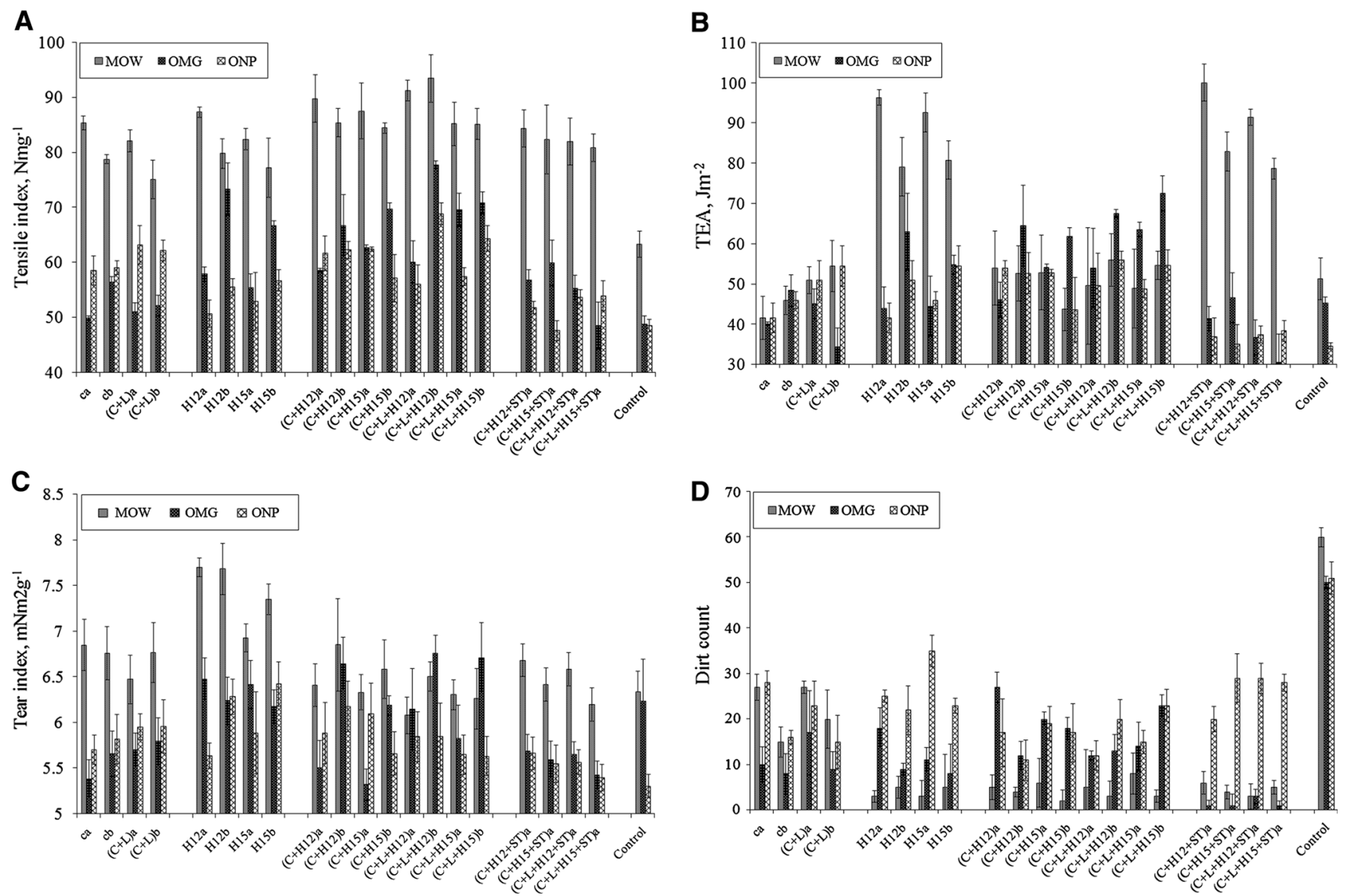

Fig. 1 Influence of enzyme, HLB and STTP on a tensile index, b TEA, $\mathbf{c}$ tear index, $\mathbf{d}$ dirt count of handsheets formed from OMG and ONP pulps. (C) Celluzyme, (L) lipolase, (H12) HLB 12, (H15) HLB 15. a $20^{\circ} \mathrm{C}, b 50{ }^{\circ} \mathrm{C}$. ST STTP. ONP results from (Mayeli and Talaeipour 2010)

pulp with combination of celluzyme/lipolase using HLB 12 at $50{ }^{\circ} \mathrm{C}(E S)$ which is 6.76 . Removing fiber fines from treated pulps resulted in improved tear index because the mean of fiber length is increased (Mayeli and Talaeipour 2010).

\section{Optical properties}

\section{Treated pulps with enzyme only $(E)$}

Results for optical properties of the control pulp and the treated pulps are summarized in Tables 4 and 5. For both MOW and OMG pulps, the improvement in optical properties of the handsheets appears to be more effective using celluzyme at $50{ }^{\circ} \mathrm{C}$ (Figs. 1d, 2). The brightness, deinking efficiency, ink area, dirt count and reduction in dirt count for treated MOW pulps are $87.51 \%, 67.4 \%, 0.355 \mathrm{~cm}^{2}$, 15 and $75 \%$, respectively, whereas the values for OMG treated pulps are $52.65 \%, 85.43 \%, 0.124 \mathrm{~cm}^{2}, 8$ and $84.31 \%$, respectively. Enzymes can remove small fibers from the surfaces of the detached ink particles (Heise et al.
1997; Sykes et al. 1998; Kim et al. 1991), i.e., enzymatic treatment through a peeling mechanism would cause the ink particles to be taken off from the surface of the cellulose (Heise et al. 1997; Sykes et al. 1998; Sykes and Tan 1997).

Treated pulps with surfactant only $(S)$

As shown in Tables 4 and 5, both MOW and OMG pulps show a significant increase in all optical properties. For MOW and OMG pulps, the improvement in optical properties is achieved using surfactant with lower HLB value (12) at $20^{\circ} \mathrm{C}$ and with higher HLB (15) at $50{ }^{\circ} \mathrm{C}$, respectively (Figs. 1d, 2). The brightness, deinking efficiency, ink area, dirt area for MOW treated pulp are $92.92 \%$, $95.04 \%, 0.054 \mathrm{~cm}^{2}$ and 3, respectively, whereas the values for OMG treated pulps are $60.14 \%, 94.36 \%, 0.048 \mathrm{~cm}^{2}$ and 7, respectively. Applying surfactant leads to elimination of more ink particles from the pulp suspension, so the optical properties increase (Jeffries et al. 1994; Mayeli and Talaeipour 2010; Shrinath et al. 1991). 
Table 4 Effect of enzyme, HLB and STTP on the optical properties of handsheets formed from MOW pulp

\begin{tabular}{|c|c|c|c|c|c|}
\hline Assay $^{A}$ & Brightness $(\%)$ & Deinking efficiency (\%) & Ink area $\left(\mathrm{cm}^{2}\right)$ & $\begin{array}{l}\text { Ink particle size } \\
\text { average }\left(\mathrm{cm}^{2}\right)\end{array}$ & $\begin{array}{l}\text { Reduction in dirt } \\
\text { count }(\%)\end{array}$ \\
\hline Control & 80.09 & - & 1.089 & 0.0181 & - \\
\hline \multicolumn{6}{|l|}{$E$} \\
\hline $\mathrm{C}^{\mathrm{a}}$ & 84.76 & 30.94 & 0.752 & 0.0278 & 55 \\
\hline $\mathrm{C}^{\mathrm{b}}$ & 87.51 & 67.4 & 0.355 & 0.0236 & 75 \\
\hline$(\mathrm{C}+\mathrm{L})^{\mathrm{a}}$ & 86.23 & 40.31 & 0.65 & 0.024 & 55 \\
\hline$(\mathrm{C}+\mathrm{L})^{\mathrm{b}}$ & 87.79 & 65.01 & 0.381 & 0.019 & 66.7 \\
\hline \multicolumn{6}{|l|}{$S$} \\
\hline $\mathrm{H} 12^{\mathrm{a}}$ & 92.92 & 95.04 & 0.054 & 0.018 & 95 \\
\hline $\mathrm{H} 12^{\mathrm{b}}$ & 90.81 & 89.16 & 0.118 & 0.0236 & 91.7 \\
\hline $\mathrm{H} 15^{\mathrm{a}}$ & 91.43 & 93.75 & 0.068 & 0.022 & 95 \\
\hline $\mathrm{H} 15^{\mathrm{b}}$ & 90.68 & 90.36 & 0.105 & 0.021 & 91.7 \\
\hline \multicolumn{6}{|l|}{$E+S$} \\
\hline$(\mathrm{C}+\mathrm{H} 12)^{\mathrm{a}}$ & 91.93 & 86.68 & 0.145 & 0.029 & 91.7 \\
\hline$(\mathrm{C}+\mathrm{H} 12)^{\mathrm{b}}$ & 90.4 & 88.15 & 0.129 & 0.0322 & 93.3 \\
\hline$(\mathrm{C}+\mathrm{H} 15)^{\mathrm{a}}$ & 91.94 & 88.43 & 0.126 & 0.021 & 90 \\
\hline$(\mathrm{C}+\mathrm{H} 15)^{\mathrm{b}}$ & 92.06 & 96.42 & 0.039 & 0.0195 & 96.7 \\
\hline$(\mathrm{C}+\mathrm{L}+\mathrm{H} 12)^{\mathrm{a}}$ & 91.69 & 87.33 & 0.138 & 0.0276 & 91.7 \\
\hline$(\mathrm{C}+\mathrm{L}+\mathrm{H} 12)^{\mathrm{b}}$ & 90.89 & 95.5 & 0.049 & 0.0245 & 96.7 \\
\hline$(\mathrm{C}+\mathrm{L}+\mathrm{H} 15)^{\mathrm{a}}$ & 89.72 & 82.83 & 0.187 & 0.0234 & 86.7 \\
\hline$(\mathrm{C}+\mathrm{L}+\mathrm{H} 15)^{\mathrm{b}}$ & 90.7 & 97.61 & 0.026 & 0.013 & 96.7 \\
\hline \multicolumn{6}{|l|}{$E+S+S T$} \\
\hline$(\mathrm{C}+\mathrm{H} 12+\mathrm{ST})^{\mathrm{a}}$ & 92.9 & 87.14 & 0.14 & 0.0233 & 90 \\
\hline$(\mathrm{C}+\mathrm{H} 15+\mathrm{ST})^{\mathrm{a}}$ & 91.81 & 93.02 & 0.076 & 0.0197 & 93.3 \\
\hline$(\mathrm{C}+\mathrm{L}+\mathrm{H} 12+\mathrm{ST})^{\mathrm{a}}$ & 92.84 & 92.74 & 0.079 & 0.0253 & 95 \\
\hline$(\mathrm{C}+\mathrm{L}+\mathrm{H} 15+\mathrm{ST})^{\mathrm{a}}$ & 91.47 & 91.92 & 0.088 & 0.0176 & 91.7 \\
\hline
\end{tabular}

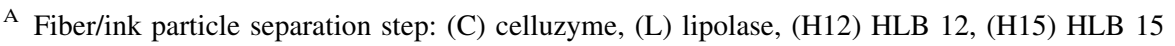

a $20{ }^{\circ} \mathrm{C},{ }^{\mathrm{b}} 50{ }^{\circ} \mathrm{C}$

$E$ Treated pulps with enzyme only

$S$ Treated pulps with surfactant only

ST STTP

\section{Treated pulps with enzyme and surfactant (ES)}

As can be seen, for both MOW and OMG treated pulps, the improvement in optical properties is achieved with combination of celluzyme/lipolase using HLB 15 at $50{ }^{\circ} \mathrm{C}$ for MOW and using HLB 12 at $50{ }^{\circ} \mathrm{C}$ for OMG pulps. The brightness, deinking efficiency, ink area, dirt count and reduction in dirt count from treated MOW pulps are $90.7 \%, 97.61 \%, 0.026 \mathrm{~cm}^{2}, 2$ and $96.7 \%$, respectively, whereas the values for OMG treated pulps are $57.26 \%$, $77.67 \%, 0.19 \mathrm{~cm}^{2}, 13$ and $74.51 \%$, respectively. Enzymatic treatment through a peeling mechanism would cause the ink particles to be taken off from the surface of the cellulose (Zöllner and Schroeder 1998). Once ink particles are floating on the water surface, they are removed by a skimming action.
Treated pulps with enzyme, surfactant and STTP (ESST)

As shown in Tables 4 and 5, the ESST system increases all of the optical properties for MOW and OMG pulps. From the results, it is clear that STTP has a significant influences on the optical properties of handsheets formed from OMG treated pulp. The results of image analysis show that elimination of the dirt count is significantly improved in OMG treated pulps with ESST system (Figs. 1d, 2). This improvement appears to be more effective after treating the pulps with celluzyme using HLB 15. The brightness, deinking efficiency, ink area, dirt count and reduction in dirt count for OMG treated pulps are $62.93 \%, 99.53 \%$, $0.004 \mathrm{~cm}^{2}, 1$ and $98.04 \%$, respectively.

The results show ink elimination, when STTP is used, for OMG pulps is highest in the case of ESST; nevertheless, 
Table 5 Effect of enzyme, HLB and STTP on the optical properties of handsheets formed from OMG pulp

\begin{tabular}{|c|c|c|c|c|c|}
\hline Assay $^{A}$ & Brightness (\%) & Deinking efficiency (\%) & Ink area $\left(\mathrm{cm}^{2}\right)$ & $\begin{array}{l}\text { Ink particle size } \\
\text { average }\left(\mathrm{cm}^{2}\right)\end{array}$ & $\begin{array}{l}\text { Reduction in dirt } \\
\text { count }(\%)\end{array}$ \\
\hline Control & 49.22 & - & 0.851 & 0.0167 & - \\
\hline \multicolumn{6}{|l|}{$E$} \\
\hline $\mathrm{C}^{\mathrm{a}}$ & 50.89 & 63.69 & 0.309 & 0.0309 & 80.39 \\
\hline $\mathrm{C}^{\mathrm{b}}$ & 52.65 & 85.43 & 0.124 & 0.0137 & 84.31 \\
\hline$(\mathrm{C}+\mathrm{L})^{\mathrm{a}}$ & 50.73 & 70.97 & 0.247 & 0.0145 & 66.67 \\
\hline$(\mathrm{C}+\mathrm{L})^{\mathrm{b}}$ & 51.5 & 82.6 & 0.148 & 0.0164 & 82.35 \\
\hline \multicolumn{6}{|l|}{$S$} \\
\hline $\mathrm{H} 12^{\mathrm{a}}$ & 57.87 & 89.77 & 0.087 & 0.0048 & 64.71 \\
\hline $\mathrm{H} 12^{\mathrm{b}}$ & 57.48 & 92.48 & 0.064 & 0.0071 & 82.35 \\
\hline $\mathrm{H} 15^{\mathrm{a}}$ & 60.17 & 91.77 & 0.07 & 0.0064 & 78.43 \\
\hline $\mathrm{H} 15^{\mathrm{b}}$ & 60.14 & 94.36 & 0.048 & 0.0068 & 86.27 \\
\hline \multicolumn{6}{|l|}{$E+S$} \\
\hline$(\mathrm{C}+\mathrm{H} 12)^{\mathrm{a}}$ & 55 & 41.36 & 0.499 & 0.0185 & 47.06 \\
\hline$(\mathrm{C}+\mathrm{H} 12)^{\mathrm{b}}$ & 55.35 & 79.67 & 0.173 & 0.0144 & 76.47 \\
\hline$(\mathrm{C}+\mathrm{H} 15)^{\mathrm{a}}$ & 56.87 & 49.47 & 0.43 & 0.0215 & 60.78 \\
\hline$(\mathrm{C}+\mathrm{H} 15)^{\mathrm{b}}$ & 52.75 & 75.79 & 0.206 & 0.0114 & 64.71 \\
\hline$(\mathrm{C}+\mathrm{L}+\mathrm{H} 12)^{\mathrm{a}}$ & 57.26 & 76.14 & 0.203 & 0.0169 & 76.47 \\
\hline$(\mathrm{C}+\mathrm{L}+\mathrm{H} 12)^{\mathrm{b}}$ & 57.23 & 77.67 & 0.19 & 0.0146 & 74.51 \\
\hline$(\mathrm{C}+\mathrm{L}+\mathrm{H} 15)^{\mathrm{a}}$ & 55.31 & 75.55 & 0.208 & 0.0148 & 72.55 \\
\hline$(\mathrm{C}+\mathrm{L}+\mathrm{H} 15)^{\mathrm{b}}$ & 57.83 & 59.45 & 0.345 & 0.015 & 54.9 \\
\hline \multicolumn{6}{|l|}{$E+S+S T$} \\
\hline$(\mathrm{C}+\mathrm{H} 12+\mathrm{ST})^{\mathrm{a}}$ & 59.02 & 99.41 & 0.005 & 0.005 & 98.04 \\
\hline$(\mathrm{C}+\mathrm{H} 15+\mathrm{ST})^{\mathrm{a}}$ & 62.93 & 99.53 & 0.004 & 0.004 & 98.04 \\
\hline$(\mathrm{C}+\mathrm{L}+\mathrm{H} 12+\mathrm{ST})^{\mathrm{a}}$ & 58.38 & 95.53 & 0.038 & 0.0126 & 94.12 \\
\hline$(\mathrm{C}+\mathrm{L}+\mathrm{H} 15+\mathrm{ST})^{\mathrm{a}}$ & 59.44 & 98.35 & 0.014 & 0.014 & 98.04 \\
\hline
\end{tabular}

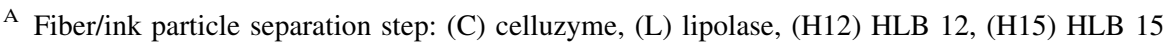

a $20{ }^{\circ} \mathrm{C},{ }^{\mathrm{b}} 50{ }^{\circ} \mathrm{C}$

$E$ Treated pulps with enzyme only

$S$ Treated pulps with surfactant only

ST STTP

dirt count for the MOW shows a slightly decreased in the presence of STTP. It is reported that enzymes and nonionic surfactants, such as ethoxylated Fatty Alcohol, are capable of assisting the detachment of offset ink particles from used papers (Jeffries et al. 1994; Mayeli and Talaeipour 2010; Misner 1992; Elegir et al. 2000). These soaps will eventually associate with detached ink particles, thereby rendering them hydrophobic. Lowest residual dirt area values and dirt counts are detected in the OMG samples which are floated with STTP and nonionic surfactant at $20{ }^{\circ} \mathrm{C}$. STTP reduces the residual dirt counts of the handsheets made from OMG deinked pulps considerably, while its brightness increases. From Figs. 1d and 2, it is clear that deinking efficiency increased meaningfully for OMG treated pulps with ESST system compared with control pulp, $E, S$ and $E S$ system. The STTP collects hydrophobic substances like ink and not only improve flotation deinking selectively but also significantly reduce the amount of ink re-deposition.

\section{Conclusion}

In this study, pulp and paper properties of deinked pulps of MOW and OMG studied under four different conditions. It is found that HLB value has a significant influence on the properties of treated pulps. The treated pulps using HLB 12 at 20 and $50{ }^{\circ} \mathrm{C}$ exhibited higher-strength properties for MOW and OMG pulps, respectively, while HLB 15 at $50{ }^{\circ} \mathrm{C}$ causes an improvement in optical properties for MOW and OMG pulps. The results show that freeness of treated MOW pulps with ESST system increased significantly compared with other pulps treated with $E, S$ ad 


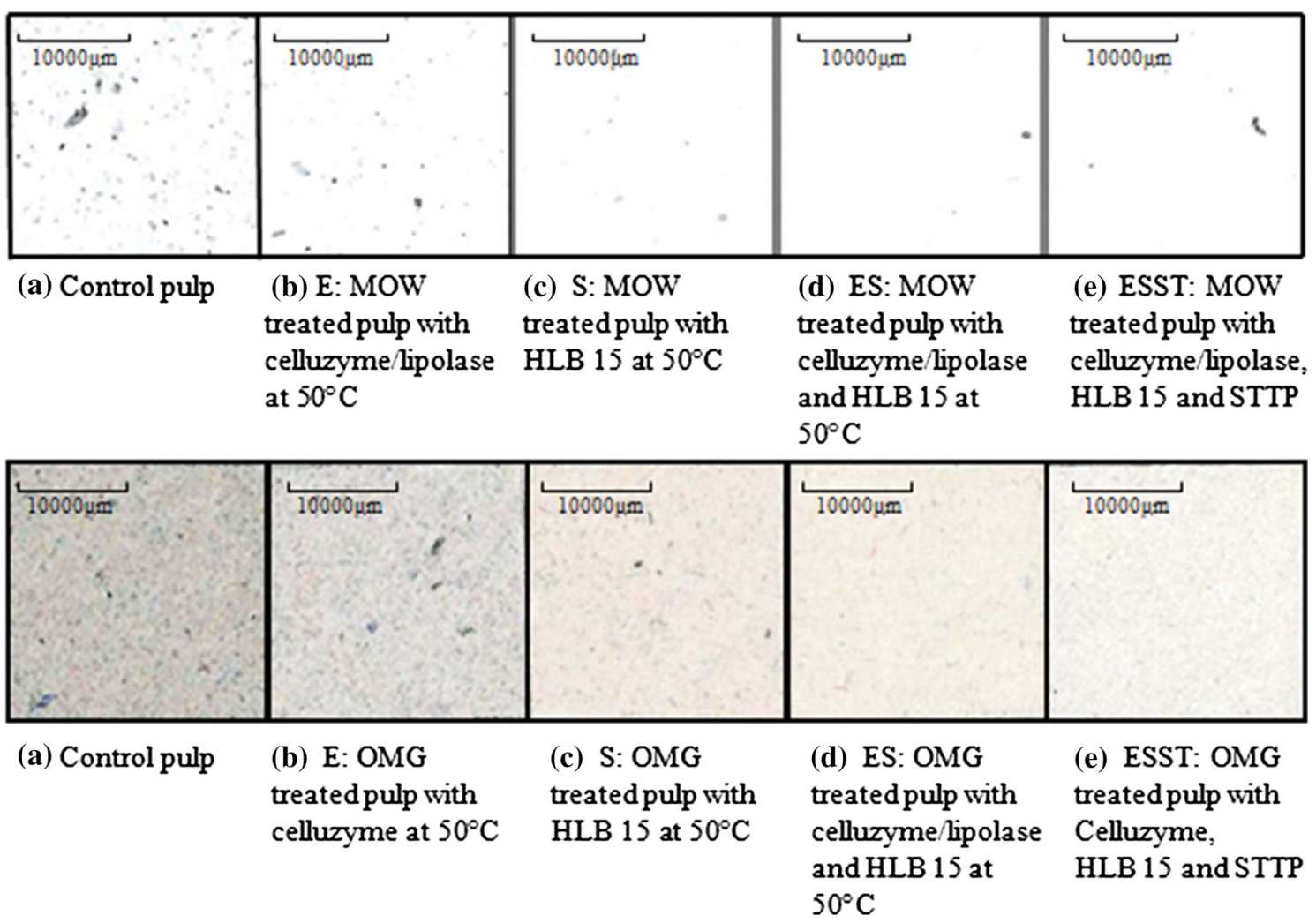

Fig. 2 Image analysis images of MOW and OMG pulps

$E S$ systems. Further, it is observed that the optical properties significantly improved with STTP. Based on the results, OMG pulps could be effectively deinked with STTP at low temperature (ESST system).

Acknowledgments The authors would like to acknowledge support from the CHOUKA company of Gilan and Mahd-e-Tage company of Tehran, Iran, for the use of laboratory facilities.

\section{References}

Bobu E, Ciolacu F, Cretu A (2008) Deinkability of mixed prints: alkaline vs. neutral deinking. Prog Pap Recycl 18(1):23-31

Elegir G, Panizza E, Canetti M (2000) Neutral enzyme deinking of office waste with amylase/cellulase xerographic assisted mixture. Tappi J 83(11):40-44

Fricker A, Thompson R, Manning A (2007) Novel solutions to new problems in paper deinking. Pigment Resin Tech 36(3):141-152

Gübitz GM, Mansfield SD, Böhm D, Saddler JN (1998) Effect of endoglucanases and hemicellulases in magnetic and flotation deinking of xerographic and laser-printed papers. J Biotechnol 65:209-215

Hannuksela T, Rosencrance S (2008) Deinking Chemistry. Published online as chapter six, deinking primer, pp 1-12

Heise OU, Unwin JP, Klungness JH, Fineran WG, Sykes MS, Abubakr S (1997) Industrial scaleup of enzyme-enhanced deinking of nonimpact printed toners. Tappi J 79(3):207-212

Ibara D, Monte MC, Blanco A, Martinez AT, Martinez MJ (2012) Enzymatic deinking of secondary fibers: cellulases/ hemicellulases versus laccase-mediator system. J Ind Microbiol Biotechnol 39:1-9

Jeffries TW, Klungness JH, Sykes S, Rutledge-Cropsey K (1994) Comparison of enzyme-enhanced with conventional deinking of xerographic and laser-printed paper. Tappi J 77(4):173-179

Jeffries TW, Sykes MS, Rutledge-Cropsey K, Klungness JH, Abubakr S (1995) Enhanced removal of toners from office waste papers by microbial cellulases. In: Sixth international conference on biotech. Pulp and Paper Industry, pp 141-144

Kim TJ, Ow SK, Eom TJ (1991) Enzymatic deinking methods waste paper. In: Tappi pulping conference proceedings, pp 1023-1031

Knudsen O, Young JD, Yang JL (1998) Long-term use of enzymatic deinking at Stora Dalum plant. In: Seventh international conference biotech. Pulp Paper Industry, pp A17-A20

Marques S, Pala H, Alves L, Amaral-Collaço MT, Gama FM, Gírio FM (2003) Characterisation and application of glycanases secreted by Aspergillus terreus CCMI 498 and Trichoderma viride CCMI 84 for enzymatic deinking of mixed office wastepaper. J Biotechnol 100(3):209-219

Mayeli N, Talaeipour M (2010) Effect of different HLB value and enzymatic treatment on the properties of old newspaper deinked pulp. Bioresour J 5(4):2520-2534

Misner M (1992) The emerging world of deinking. Waste Age, pp 86-94

Morrow H, Horacek B, Hale K, Rosencrance S (2005) True-neutral deinking. Paper Age 121:34-35

Nakano J (1993) Recent research trends of pulping chemistry. Appik J 25(1):85-91

Oh JT, Park KN, Park JW, Kim JH (1997) Effects of HLB value of surfactant on enzymatic deinking process. J Ind Eng Chem $3(1): 7-12$ 
Patrick K (2004) Enzyme technology improves efficiency, cost, safety of stickies removal program. Paper Age 120(6):22-25

Pèlach MA, Pastor FJ, Puig J, Vilaseca F, Mutjè P (2003) Enzymic deinking of old newspapers with cellulase. Process Biochem J 38(7):1063-1067

Rutledge-Cropsey K, Klungness JH, Abubakr S (1998) Performance of enzymatically deinked recovered paper on paper machine runnability. Tappi J 81(2):148-151

Senior DJ, Hamilton J (1992) Biobleaching with xylanses brings biotechnology to Reality. Pulp Paper 66(9):111-114

Shrinath A, Szewczak JT, Bowen IJ (1991) A review of ink removal techniques in current deinking technology. Tappi J 74:85-93

Sykes MS, Tan F (1997) Enzymatic removal of stickie contaminants. In: Tappi pulping conference proceedings, pp 687-691

Sykes MS, Klungness JH, Gleisner R, Abubakr S (1998) Stickie removal using neutral enzymatic repulping and pressure screening. In: Tappi recycling, symposium notes, pp 291-297

Vyas S, Lachke A (2003) Biodeinking of mixed office waste paper by alkaline active cellulases from alkalotolerant Fusarium sp. Enzyme Microb Technol 32(10):236-245
Xu QH, Fu Y, Gao Y, Qin M (2009) Performance and efficiency of old newspaper deinking by combining cellulase/hemicellulase with laccase-violuric acid system. Waste Manag J 29(5):1486-1490

Xu Q, Wang YP, Qin MH, Fu YJ, Li ZQ, Zhang FS, Li JH (2011) Fiber surface characterization of old newsprint pulp deinked by combining hemicellulase with laccase-mediator system. Bioresour J 102(11):6536-6540

Zeyer C, Joyce TW, Heitmann JA, Rucker JW (1994) Factors influencing enzyme deinking of recycled fiber. Tappi J 77(10):169-177

Zhang X, Renaud S, Paice M (2008) Cellulase deinking of fresh and aged recycled newsprint/magazines (ONP/OMG). Enzyme Microb Technol 43(2):103-108

Zöllner HK, Schroeder LR (1998) Enzymatic deinking of nonimpact printed white office paper with a-amylase. Tappi J 81(3):166-170 